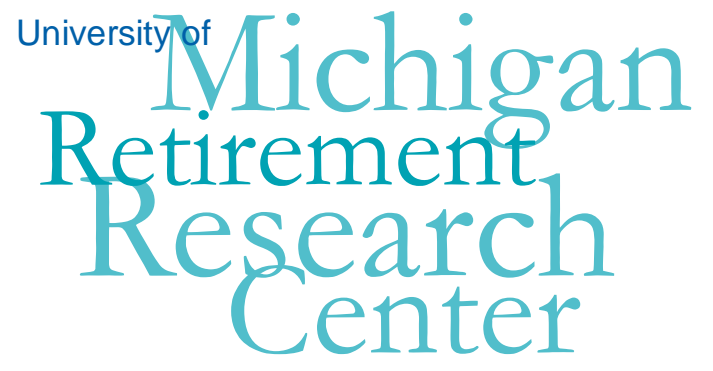

Working Paper

WP 2010-228

The Effects of the Financial Crisis on the WellBeing of Older Americans: Evidence from the Cognitive Economics Study

Matthew D. Shapiro

\begin{tabular}{|l|l|}
\hline $\mathrm{M}$ & $\mathrm{R}$ \\
\hline $\mathrm{R}$ & $\mathrm{C}$ \\
\hline
\end{tabular}

Project \#: UM10-07 


\title{
The Effects of the Financial Crisis on the Well-Being of Older Americans: Evidence from the Cognitive Economics Study
}

\author{
Matthew D. Shapiro \\ University of Michigan and NBER
}

September 2010

\author{
Michigan Retirement Research Center \\ University of Michigan \\ P.O. Box 1248 \\ Ann Arbor, MI 48104 \\ http://www.mrrc.isr.umich.edu/
}

(734) 615-0422

\section{Acknowledgements}

This work was supported by a grant from the Social Security Administration through the Michigan Retirement Research Center (Grant \# 10-M-98362-5-01). The findings and conclusions expressed are solely those of the author and do not represent the views of the Social Security Administration, any agency of the Federal government, or the Michigan Retirement Research Center.

\section{Regents of the University of Michigan}

Julia Donovan Darrow, Ann Arbor; Laurence B. Deitch, Bingham Farms; Denise Ilitch, Bingham Farms; Olivia P. Maynard, Goodrich; Andrea Fischer Newman, Ann Arbor; Andrew C. Richner, Grosse Pointe Park; S. Martin Taylor, Gross Pointe Farms; Katherine E. White, Ann Arbor; Mary Sue Coleman, ex officio 


\title{
The Effects of the Financial Crisis on the Well-Being of Older Americans: Evidence from the Cognitive Economics Study
}

\begin{abstract}
This paper uses the Cognitive Economics Study (CogEcon) to assess the effect of the financial crisis on the well-being of older Americans. Financial wealth fell by about 15 percent for the median household. These financial losses were concentrated among households with high levels of wealth and high cognitive capacities, who tend to have higher exposure to the stock market. Nonetheless, households with little financial wealth suffered declines in well-being-measured by declines in consumption-as large on average as households with substantial exposure to the stock market. Tight credit market conditions and adverse labor market outcomes account for much of the effect of the financial crisis on the consumption of these low-wealth households.
\end{abstract}

\section{Authors’ Acknowledgements}

The research reported herein was pursuant to a grant from the U.S. Social Security Administration (SSA) funded as part of the Retirement Research Consortium (RRC). The findings and conclusions expressed are solely those of the author and do not represent the views of SSA, any agency of the Federal Government, or the RRC and the MRRC. Additional support from National Institute on Aging program project grant 2-P01-AG10179 is gratefully acknowledged. The superb research assistance of Cynthia Doniger, Brooke Helppie, and Joanne Hsu in preparing the CogEcon data and of Eleanor Dillon in preparing this paper is also gratefully acknowledged. A preliminary version of this paper "Cognition, Financial Wealth, and the Effects of the Financial Crisis on the Well-Being of Older Americans" was presented at the 12th Annual Joint Conference of the Retirement Research Consortium, August 5-6, 2010, Washington, DC. The comments of Gary V. Engelhardt are gratefully acknowledged. 
The financial crisis that began in fall 2008 led to the deepest and most persistent economic downturn since the Great Depression. This paper uses the Cognitive Economics Study (CogEcon) to examine how the financial crisis affected the well-being of older Americans. ${ }^{1}$ The CogEcon study has several features that provide distinctive insights into this question. The initial wave of the CogEcon study (CogEcon 2008) was fielded shortly before the financial crisis that began in the fall of 2008. It provides baseline wealth measurements and very detailed information about the structure of households' portfolios for a representative sample of U.S. individuals aged 50 years and older. In addition to this information on wealth and portfolios, the CogEcon study has a wide range of preference and cognition measures, including measures of risk preference, expectations, financial knowledge and attitudes, and cognitive status, that should partially determine households’ portfolio choices.

A second wave was fielded in early summer 2009. This CogEcon 2009 Post-crash survey was designed to provide direct evidence on the effects of the financial crisis that began in September 2008. The post-crash study re-measures some of the CogEcon 2008 variables, but largely consists of questions to assess the changes in circumstances, attitudes, and plans that followed from the financial crisis. The combination of baseline measures of CogEcon 2008 and the change measures of CogEcon 2009 thus provide an important set of data for assessing how the financial crisis affected older Americans.

\footnotetext{
${ }^{1}$ The CogEcon study was developed by the NIA program project P01-AG10179 under the leadership of Robert Willis. The sample frame and cognitive measures in the CogEcon study are from the CogUSA project. The CogUSA project, under the leadership of Jack McArdle of the University of Southern California, was established to improve the cognitive measurements in the Health and Retirement Study (HRS). In addition to Willis, University of Michigan faculty Gwen Fisher, Miles Kimball, Matthew Shapiro, and Tyler Shumway and graduate students Brooke Helppie and Joanne Hsu had roles in designing and fielding the CogEcon study.
} 
This paper links several key findings. Holding a high fraction of wealth in the form of stock is correlated with having high cognitive status. Nonetheless, households with low levels of wealth reported being substantially affected by the financial crisis. These findings provide a nuanced picture of the effects of the financial crisis across older Americans. Those with disproportionate exposure to the financial crisis by virtue of having high shares of stock in their portfolios tend to have substantially higher cognitive capacity and greater wealth than average. This finding raises the possibility that those most directly affected by the stock market crash were well equipped to adjust to it. By construction, households with little total wealth were not directly affected by the financial crisis because they had no financial wealth at stake. Nonetheless, they report similar downward adjustments in consumption and delays in the expected date of retirement as households that experienced substantial financial losses. This finding points to effects of the financial crisis on economic security that greatly exceeded the direct loss of value in the stock market. The paper will examine credit and labor market factors that help explain the overall effects of the financial crisis and how it affected different households differently.

\section{Who was affected by the financial crisis?}

The financial crisis led to a large decline in stock market value with potentially very serious implications for retiree finance. By definition, the decline in the stock market directly affects only stockholders. This section will document some key characteristics of stockholders: They have relatively high wealth and relatively high cognitive status. Hence, stockholders, with relatively high wealth and relatively high cognitive capacity on average, might be better equipped than the average household to adjust to the financial crisis. On the other hand, the 
financial crisis was not just about a decline in the stock market. It involved a sharp decline in housing equity, a sharp increase in unemployment, and broad disruptions of credit markets. The CogEcon study, particularly its post-crash survey, was designed to assess all of these developments.

Table 1 shows the loss in financial wealth as a consequence of the financial crisismeasured as the percent change from July 2008 to the date of the CogEcon 2009 in early summer 2009. Table 2 shows the components of financial wealth. ${ }^{2}$ The first two columns of these tables give the initial level of wealth. The next four columns give the mean, 25th percentile, median, and 75th percentile of the percent change in wealth.

Overall, the median decline in wealth was 15\% among all wealth holders (top line of Table 1). To get a greater sense of this heterogeneity, the next two lines divided the wealth holders into those who lost at least 10 percent and those who lost less than 10 percent. Those who lost at least 10 percent had substantially more wealth—almost twice the mean wealth and 31/2 times the median wealth. Higher wealth households have, on average, greater exposure to the stock market. Consequently, they experienced greater losses in the financial crisis. Indeed, conservatively invested portfolios, e.g., those weighted heavily toward Treasury securities, had lower losses or even gains.

\footnotetext{
${ }^{2}$ The CogEcon 2009 Post-Crash survey does not replicate the complete battery of wealth questions from the 2008 survey. Instead it asks about a few important categories of wealth. In this paper, total financial wealth is the value of retirement accounts plus cash (bank accounts, money market mutual funds, and Treasury bills) and stock outside of retirement accounts. The survey asks for the percent change in the value of these assets since July 2008. These percent changes are tabulated in the Tables 1 and 2. The July 2008 values are calculated by applying these percent changes to the 2009 values. There is ambiguity about whether respondents are using current or 2008 values as the denominator in computing the percent changes. For large changes, this distinction is significant. To calculate the 2008 levels, this paper uses the chained approach, that is, it treats the reported percent change as if it were the average of the of the base period and current period percent changes. In separate research, the CogEcon study team is exploring the difference between measuring change in wealth using the point-to-point comparisons of the levels versus the reported percent changes.
} 
The next panel of Table 1 shows the relationship of the level and change of financial wealth with cognition as measured by the number series score, which is a measure of fluid intelligence. ${ }^{3}$ The rows give the statistics for wealthholders by the terciles of this score. There is a powerful relationship between both the level of fluid intelligence and both the level of wealth and the size of the loss. Both wealth and exposure to the stock market are increasing functions of cognition. Table 3 shows just how powerful the relationship is between cognition and stock ownership. Among wealthholders, the high cognition third of the sample has a median stock share of 41 percent while the low cognition third of the sample has a median stock share of 7 percent. Combined with the evidence from Table 1, what emerges is that the high cognition group has more wealth and more of it in stock. Hence, those with high cognition took larger financial losses in the financial crisis. Put differently, low cognition individuals faced relatively low financial losses because they had relatively little stock.

Explaining the relationship between cognition, wealth, and the demand for risky assets is complicated. The demand for risky assets should be related to the level of risk tolerance. The Cognitive Economics Study (CogEcon) contains the risk tolerance questions developed by Barsky, Juster, Kimball, and Shapiro (1997 [BJKS]). The version of the question used on the CogEcon poses the following hypothetical. The respondent has inherited a million dollars and must make a once-and-for-all choice of investing it in a safe asset or a risky asset. The risky asset has a 50-50 chance of doubling or falling by various fractions. The respondent is asked whether he or she prefers the safe return or the risky return for different levels of the downside risk. This partitions respondents into six risk tolerance categories.

Using the techniques of BJKS and Kimball, Sahm, and Shapiro (2008 [KSS]), this paper imputes a value of relative risk tolerance (the inverse of relative risk aversion) to each

\footnotetext{
${ }^{3}$ The number series score is based on the ability to complete sequences of numbers.
} 
respondent to the CogEcon study. Table 4 shows a powerful correlation between "number series” (NS)—a standardized measure of fluid intelligence-and the level of relative risk tolerance. In separate work, Shapiro (2010) is examining whether it is possible to separate the channels by which cognition affects the demand for risky assets, i.e., whether it is solely through the preference channel documented in Table 4, or whether there are independent effects of cognition on holding stocks, e.g., through understanding the stock market. For the purposes of this paper, it is simply important to know that those with high stock exposure during the financial crisis had that exposure based on choices that are powerfully related to having high cognitive status.

So far the discussion has focused on financial losses. It is important to bear in mind that a substantial minority of households have little direct exposure to financial markets by virtue of having little financial wealth. The last line of Table 1 reveals that about $20 \%$ of households in the 50+ age group have little financial wealth and therefore minimal direct exposure to the stock market crash. This group will be an important feature of our analysis. Notwithstanding its low exposure to the stock market, it turns out to have been substantially affected by the financial crisis.

The financial crisis of 2008-2009 originated in the housing market. Housing prices peaked in 2006 — well in advance of the crisis. The ensuing financial distress, both at the household and systemic levels, gave impetus to the crisis and also has propagated its effects. Housing price increases do not add net wealth to the society at large_-an increase in housing prices raises asset values but also the cost of housing consumption. Older households, however, may plan to disinvest in housing, so housing capital gains can translate into an increase in nonhousing consumption for the CogEcon population. Inversely, the sharp, economy-wide drop in 
housing prices could have a direct effect on well-being. Moreover, though the older population tends to have lower mortgage debt than the population at large, some older households have high debt tied to their house value.

This paper will examine both the direct loss in home value and credit issues. The last two lines of Table 2 show the exposure of the CogEcon sample to the housing market. In this population, homeownership is ubiquitous. About $90 \%$ of the sample owns their home. The median value of the homes was $\$ 213,890$ in July 2008 . The median decline in home value was $10 \% .{ }^{4}$ This loss in wealth is of similar order to the loss in financial wealth, and is spread over the population much more evenly.

Financial wealth and housing wealth are important, though far from complete, measures of resources. In particular, they ignore human capital, both future wages and the value of pensions and Social Security. Table 5 gives additional measures of economic and cognitive status that will be used in the subsequent analysis—all measured at the 2008 baseline. The first column gives the distribution of total family income. ${ }^{5}$ Mean and median family income are approximately $\$ 116,000$ and $\$ 75,000$, which are higher than the U.S. population statistics owing to the relative affluence of the population aged over 50 years. ${ }^{6}$ The column for wealth includes all respondents with valid wealth data (both those with at least $\$ 10,000$ in wealth and those with less than that amount [top and bottom lines of Table 1]). The last column gives the distribution of the number series score.

\footnotetext{
${ }^{4}$ This decline in home value is based on the CogEcon 2009 question that asks about change in value in the respondent's neighborhood. The 2008 levels are computed based on the 2009 reported value and the percent changes (see footnote 2).

${ }^{5}$ CogEcon has only this limited measure of income. Plans for future waves include more detailed information about current income and future pension/Social Security entitlements.

${ }^{6}$ The wealth and income in the CogEcon are reasonably close to those found in the HRS.
} 


\section{Credit and Labor Market Effects of the Financial Crisis}

The financial crisis had much broader implications for households than the loss of value of financial assets and housing discussed in Section I. In this section, we use the CogEcon study to document credit market distress and labor supply effects of the crisis.

The CogEcon 2009 Post-crash survey includes a battery of questions concerning financial distress. Specifically, it asks whether since July 2008 the respondent has done any of the following:

1. Gotten credit from a rent-to-own store, pawn shop, payday lender, cash advance lender, auto title lender, or tax return preparer;

2. Made a late payment on any loan;

3. Been denied credit for any type of loan;

4. Lost a home or property due to a bank foreclosure;

5. Received substantial financial help from a friend or relative;

6. Had any credit card or home equity loan cancelled by the lender; or

7. Had the credit limit on any credit card or home equity loan reduced by the lender. Take 6 shows the incidence of these indicators of financial distress. The last two lines summarize them by tabulating whether any or at least two of these indicators were reported. Foreclosure is exceedingly rare in this population. Late payments, credit denials, and reduction of credit lines are more commonly reported indicators of financial distress. About a quarter of respondents reported any financial distress; $8.4 \%$ reported two or more indicators. The retired are much less likely to report financial distress than the non-retired. Having low cognition is somewhat associated with high financial distress. Most strikingly, those with no assets—either no house or no financial assets have a dramatically higher likelihood of reporting financial 
distress. This finding, of course, is not surprising. Those on the edge financially—with no tangible assets—lack a financial buffer. Nonetheless, Table 6 conveys an important message about thinking about the effects of the declines in the value of financial assets and housing. Those that suffered substantial losses in value are starting from a relatively high-wealth position. Those without tangible assets face financial distress despite having no financial losses owing to the crisis. The systemic effects of the credit crisis that caused access to credit be sharply curtailed could have substantial effects on households with little or no assets. ${ }^{7}$

The sharp decline in employment is another salient feature of the financial crisis. Employment peaked in late 2007 and began to fall sharply in mid-2008. At the time of the CogEcon 2009 Post-crash survey, total payroll employment had been falling by over 600 thousand jobs per month for the better part of a year. Unemployment increased sharply and the duration of unemployment also increased dramatically. This very adverse labor market could have substantial effects on the population of older Americans. For those still working, job loss became more likely, and the probability of subsequent reemployment fell. For those contemplating leaving their long term job, either for full retirement or a bridge job, the option value of keeping the lifetime job increased: The probability of finding a bridge job fell, and the prospects for or re-entering the workforce if retirement did not work out declined.

Table 7 presents some information about the labor market experience of the CogEcon 2009 Post-crash respondents. The top panel gives the distribution of retirement status. Forty percent of respondents are in retired households. ${ }^{8}$ There are some interesting differences

\footnotetext{
${ }^{7}$ This seven-item financial distress battery is only in the 2009 survey. Moreover, unlike some question in the 2009 survey, the financial distress battery is unconditional, i.e., it does not predicate the question on the financial crisis. The 2008 survey has a three-item financial distress battery (pawnshop loan, late payment, denied credit). The lowwealth households have a disproportionate level of financial distress in the 2008 baseline.

${ }^{8}$ Here and throughout this paper, retirement is defined at the household level. An individual is coded as retired if he or she was retired and, if applicable, the individual's partner was also out of the labor force.
} 
between the retired and nonretired. The retired have lower cognitive status. They are older, and fluid intelligence declines with age. Specifically, among those in the lowest tercile of number score, 58 percent are retired while 42 percent are not. Among those in the top tercile of number score, 22 percent are retired while 78 percent are not. The retired are also less likely to have had large financial losses owing to their lower exposure to the stock market. ${ }^{9}$

The lower panel of Table 7 refers to nonretired individuals. It reports responses to a battery of questions about labor market adjustments. The survey asks whether the respondent or spouse has changed hours, lost a job, or gone back to work since July 2008. The modal outcome is no change in hours and no lost job. Within those changing hours, some increased and others decreased, with more decreases than increases. About one-fifth reported going back to work, with those with no wealth or substantial losses in wealth more likely to do so than those with more modest losses or gains.

The final labor market outcome addressed in the CogEcon is change in expected retirement date. For this variable, the strategy in the CogEcon Post Crash survey was to ask about changes in expected retirement owing to the financial crisis. Since this approach is distinctive, it is important to be clear about the precise questions. First, non-retired respondents are asked, “At what age do you plan to retire completely?” They are then asked, “As a result of the economic crisis, has the age at which you plan to retire changed since July 2008?” Those responding yes are then asked, “As of July 2008, at what age were you planning to retire completely?"10

\footnotetext{
${ }^{9}$ Recall that government bonds had substantial gains during the crisis which, in conservative balanced portfolios, largely offset the stock market losses.

${ }^{10}$ Brooke Helppie of the CogEcon study team is preparing a dissertation chapter that will do a structural analysis of the lengthening of time spent working in response to the crisis.
} 
The last two lines of Table 7 show that there are dramatic increases in expected retirement age owing to the financial crisis. Almost 40 percent of the nonretired respondents indicated that they would change their years of work owing to the financial crisis. The mean increase in work is 1.32 years. This includes the zero increase for those not planning to work longer, so the mean increase conditional on retiring later is several years. The response is greater for those with greater capital losses from the financial crisis. Interestingly, those with no wealth show as big a mean increase in years worked as those with substantial losses. This result points to widespread effects of the crisis beyond the direct effects on balance sheets of individuals. CogEcon finds a bigger effect on retirement plans than studies that have looked at stock market expectations alone. ${ }^{11}$ Again, the financial crisis had much broader implications for retirement than the change in the stock market alone owing to the correlated, adverse movements in housing prices and employment (re-employment/bridge job) prospects.

\section{How did the financial crisis affect consumption?}

The previous sections show how the effect of the financial crisis has multiple dimensions. The CogEcon 2009 Post-crash survey finds losses in financial assets and housing wealth that align well with aggregate data. There is substantial heterogeneity in exposure to these asset marketsboth in terms of levels of asset and rate of capital loss. There is also substantial heterogeneity in resources to buffer against the fallout of the financial crisis. Households differ in levels of wealth and income. They also differ in labor force attachment and job prospects. Using the

\footnotetext{
${ }^{11}$ Using HRS data, Sevak (2002) uses the defined benefit/defined contribution distinction in pension plans to show that workers with DC plans retired earlier when the stock market has done well. Hurd, Reti, and Rohwedder (forthcoming) find no effect of stock market wealth on retirement plans. Goda, Shoven, and Slavov (2010) find evidence for some effect of the stock market on retirement using the 1998-2008 HRS sample, but only in the later part of the sample.
} 
CogEcon data, this paper can link together differing cognitive capacities, differing economic situations, and the consequences of the crisis for older Americans.

\section{A. Measuring the consumption response}

The change in consumption is a comprehensive measure of how well-being changes. Older individuals should not be liquidity constrained because they are no longer on the upward portion of the age-earnings profile. Changes in consumption should therefore move proportionately with changes in lifetime resources—-the sum of the present value of labor income, pensions, and Social Security, and financial assets. If components of consumption are additively separable in the utility function, then any one component can be used as an indicator of lifetime resources. It is customary to focus on nondurable consumption expenditures for such exercises (Hall, 1978, 1988) because the flow of consumption expenditure of nondurables is most likely to correspond to the flow of utility. In contrast, durables expenditures provide service flows over long periods of times, which complicates their use for assessing instantaneous utility (Mankiw, 1982). ${ }^{12}$

The CogEcon 2009 Post-crash survey asks respondents directly about the response of their consumption to the financial crisis. This line of questioning begins with the preamble

Some people have made adjustments in response to the economic crisis that began in the fall of 2008. Please tell us about any changes you and all those living with you have made since July 2008.

They are then asked, "Since July 2008, how have you and your household changed your spending on food that you use at home?" and similarly for "eating out" and "nondurable goods such as clothing, entertainment, transportation, recreation (including vacations), etc.?” For each of these categories of consumption, the respondents were asked to check off a box corresponding

\footnotetext{
${ }^{12}$ Services are also complicated. Expenditure on utilities provides flow utility, but is not separable from housing. Medical expenditures are clearly durable though classified as services. Some services, such as dry-cleaning, are nondurable. Given the limited survey time, we could not get deeply into these measurement issues.
} 
to decreases of more than $10 \%, 6-10 \%$, or $1-5 \%$, no change $(0 \%)$, or increases of $1-5 \%, 6-10 \%$, or more than $10 \%$. We translate these ranges into a single value using the mid-point of the range and plus or minus $15 \%$ for the open-ended ranges.

There are several reasons that we ask for individuals to report their response of consumption conditional on the crisis rather than comparing point-to-point measures of consumption. The first is practical. We do not have a comprehensive measure of consumption in the CogEcon 2008 baseline. ${ }^{13}$ Additionally, using point-to-point consumption measures are notoriously noisy. We attempted to get better measurements by asking about changes directly. The second issue is methodological. The survey question is designed to have the respondents condition on the effects of the crisis. While this might be hard for them to do, it is also hard to do so econometrically.

Table 8 summarizes the response to the consumption change questions. The first three lines show the percent change since July 2008 for food at home, food away from home, and other nondurables. The fourth line gives the percent change for the composite, total nondurables. ${ }^{14}$ The columns break the statistics into those who had larger and smaller financial losses, or no wealth at all (less than $\$ 10,000$ financial wealth). Overall, consumption dropped 3 percent in response to the financial crisis. Assuming standard lifecycle/permanent income behavior, this is a permanent decline. As expected, food at home dropped less while food away from home and other nondurables fell more.

\footnotetext{
${ }^{13}$ CogEcon 2008 does have the level of food consumption (see Table 5). We did not ask the corresponding level in 2009 owing to constraints on survey time and the decision to use the percent change approach discussed here.

${ }^{14}$ The composite is the simple average of food at home, food away from home, and other nondurables. Conceptually, the correct weights are the marginal expenditure shares. These are likely to be very different from the average expenditure shares. In particular, food at home is an order of magnitude larger than food away from home, but much less responsive to income and wealth. Additionally, the percent changes are likely to be measured with error. If the error variance across categories is similar, that tends to equalize the weights. Clearly, it would be possible to do something more sophisticated than averaging, but the outcome of such an exercise is likely not to be substantially different from a simple average.
} 
The overall level of consumption decline makes a good deal of sense given the magnitude of the shock. Housing and financial wealth fell 10 and $15 \%$ respectively. These assets are only a fraction of most households' lifetime resources, which include future earnings, pensions, and Social Security. Additionally, the initial drop in consumption could be attenuated by adjustment costs, habit, or an expectation of a rebound in asset values.

The heterogeneity in response of consumption is also very interesting. Those who lost more wealth report larger declines in consumption as one would expect. Those who have little wealth, however, look more like those who had big losses than those who had more modest losses. This same U-shaped response is found for the response of labor discussed above. Thus for both consumption and labor supply, those with little wealth are as much affected by the economic crisis as those with substantial losses. The response of consumption to the crisis is fairly flat across the level of cognition. That opens the possibility that there are offsetting factors related to cognitive capacity—-high exposure to the stock market among the high cognition group might be offset by a greater capacity of high cognition individuals to buffer shocks. The effects of owning a home are also instructive. The small minority who do not own a home are more exposed to the crisis using the consumption metric as the majority of homeowners. The multivariate analysis of the next subsection will attempt to sort out these channels through which the crisis affected consumption.

The CogEcon 2009 Post-crash survey also includes a question about delaying or cancelling the purchase of a car in response to the crisis. The responses to these questions are tabulated in the last line of Table 8 . Overall, $16 \%$ of respondents delayed purchasing a vehicle. There is the same U-shaped pattern in response to wealth changes: those with little wealth look like those with large losses. 


\section{B. Analyzing the consumption response}

The effects of the financial crisis are quite complicated. There is the direct effect of capital losses on financial assets and housing. But those without assets, and who therefore did not have capital losses, were also strongly affected by the crisis. Section II suggests that credit and labor market conditions were important for some households. Additionally, cognitive capacity appears to have a role in buffering the effect of the crisis. As Section I shows, high cognition individuals were more exposed to the financial crisis by virtue of having greater stock market exposure, but they also might have capacity or resources to better deal with adverse shocks. High cognition is correlated with many factors — education and wealth notably—which also are resources for buffering adverse shocks. This section pursues a multivariate approach to sort out the influence of financial, credit market, labor market, and cognitive factors on the effects of the financial crisis on the well-being of older Americans. Specifically, we now turn to considering a regression of the composite consumption change measure on these factors plus standard demographic variables. ${ }^{15}$

Wealth. Tables 9A and 9B report the results of this multivariate analysis. The first column focuses on the direct effect of wealth. The dependent variable is the percent change in consumption. The independent variables include the percent change in financial wealth (tabulated in Table 1) and a dummy for having little financial wealth (less than $\$ 10,000$ in retirement accounts, cash or equivalent, or stocks outside of retirement accounts). It also includes dummies for being the financial respondent within a couple, sex, education, and race. Age is measured continuously (by decade). Observations are at the individual level, so

\footnotetext{
${ }^{15}$ The labor supply response could be treated as a separate outcome variable. We are pursuing that approach elsewhere.
} 
households with two respondents are in the regression twice. ${ }^{16}$ The effect of the change in financial wealth on consumption growth is substantial and tightly estimated. The mean change in wealth is $15 \%$, so the estimated coefficient of 0.019 corresponds to a 0.3 percentage point drop in consumption, on average, from the capital losses on financial wealth owing to the crisis. ${ }^{17}$

The multivariate analysis confirms that the effect of the financial crisis on those with little wealth was substantial. The marginal effect on consumption growth of being in this group is to reduce consumption by almost 2 percentage points—-much larger than the direct effect of capital losses for wealthholders. This direct effect of having no wealth becomes attenuated by the inclusion of other factors correlated with having little wealth, but it will remain a substantial part of characterizing the financial crisis.

Demographics. Briefly consider the demographic covariates. Being a financial respondent reduces consumption growth and being male raises it. Financial respondents are disproportionately male, so these effects are somewhat offsetting. Being highly educated leads to a substantial and statistically significant fall in consumption following the crisis. Blacks suffered almost a 2 percent excess decline in consumption. There is a strong effect of age on consumption growth.

\footnotetext{
${ }^{16}$ The CogEcon survey design is to give the same survey to both partners, if possible. In the regressions and most of the tables, the responses are at the individual level. Therefore, we have two reads on the consumption growth for many households. These are pooled in the regressions. (Standard errors are clustered at the household level.) Some variables are defined at the household level. For each couple, we designate a financial respondent based on reports of which respondent knows more about the financial variables. (A dummy for financial R is included in the regression.) For the wealth variables (levels and percent changes), we use the financial R's responses for both members of the couple. Recall also the retirement variable is defined at the couple level (retired means both members are retired).

${ }^{17}$ This coefficient is not the standard MPC out of wealth, which is estimated in specifications using levels of variables. See Palumbo, Rudd, and Whelan (2006) for a recent estimate of the MPC in that setting.
} 
Column 2 of Table 9A adds a dummy for being retired (both retired if a couple). Being retired reduces the decline in consumption according to the point estimate, but the effect has a large standard error.

Housing and economic status. The financial crisis had effects far beyond the stock market. Indeed, the decline in house prices started several years in advance of the crisis. Columns 3 and 4 broaden the range of variables for explaining the reaction to the financial crisis by adding covariates relating to home ownership and overall economic status. These regressions include a dummy for being a homeowner and a measure of the change in the value of the home. Recall from the discussion of homeownership (Table 2) that almost 90 percent of individuals in the CogEcon are homeowners. Hence, it is not surprising that the homeownership dummy is not statistically significant, though its point estimate is large. The magnitude of the coefficient of change in home value (measured based on self-reported assessment of change of home values in the respondent's neighborhood) is similar to that for the change in wealth, though it has a somewhat larger standard error. Overall, the point estimates relating to the effect of homeownership on change in consumption are in line with those of financial wealth, but the sample has too little variation to say anything precise about the size of these effects. ${ }^{18}$

Column 4 adds the log levels of income, food expenditure, and wealth—all measured as of 2008. Income and food consumption have effects that are imprecisely estimated. The effect of wealth is positive and significant.

Cognition. The results earlier in the paper show a powerful association between cognition and economic outcomes. High cognition individuals have greater wealth and greater

\footnotetext{
${ }^{18}$ Housing wealth should not have the same effect on spending as financial wealth. In particular, changes in the value of housing also change the cost of living. Older households, however, are net sellers of housing (either currently or in the relatively near future), so capital losses in housing should put downward pressure on their consumption.
} 
stock market exposure. On the other hand, low cognition individuals appear to be disproportionately affected by the crisis. Since cognition is related to so many aspects of economic and social status, it is not clear whether it has an independent effect on how the crisis affected individuals, or whether it is a proxy for other correlates of cognition such as age, education, or wealth. The multivariate approach pursued here addresses this question. Table 9A introduces cognition into the regression specification in column 5. Several interesting results emerge from this specification. First, cognition is strongly significant in explaining the response of consumption to the financial crisis even after controlling for demographics, economic status, and the direct effects of changes in the value of financial wealth and housing. The high cognition tercile experiences about a percentage point less decline in consumption than the middle tercile. The bottom tercile has a positive coefficient, but a large standard error. Second, contrary to what one might have guessed from the one-way tabulations presented in the previous section, what emerges from the multivariate analysis is that the high cognition group does distinctly better while the middle and low cognition groups look similar. Having controlled for wealth loss—which is positively correlated with having high cognition—high cognition status appears to be a buffer against consumption declines during the crisis.

Financial distress. A substantial minority of respondents to the CogEcon 2009 Postcrash survey reported indicators of financial distress. Table 9A, Column 6 reports a regression adding a dummy variable for reporting two or more of these indicators of financial distress. Having this indicator of financial distress is a powerful explanatory variable for the change in consumption. It reduces consumption growth by about 3-3/4 percentage points. Including this financial distress indicator also somewhat attenuates the coefficients on having low financial wealth and being a homeowner, suggesting that an important channel for the effects of low 
wealth is increased susceptibility to financial distress. These changes are not statistically significant because of the inclusion of the level of wealth and income in the specification, which are collinear with the low-wealth indicator.

While the drop in consumption associated with financial distress is very large, it is unlikely to be permanent. Credit constrained individuals cannot smooth consumption over time. A tightening of credit conditions, all other things equal, would reduce the consumption of the credit constrained temporarily.

Labor supply. Adjustments to labor supply should go hand-in-hand with adjustments in consumption. Ten percent of those not retired report losing a job as a consequence of the financial crisis. This off-the-labor-supply-curve outcome has a significant impact on consumption as reported in Table 9B, Column 1. Whether it is permanent or not is hard to assess. Older individuals losing jobs might rationally view such a job loss as having a significant impact on permanent income. More generally, labor supply and consumption are related by the static first order condition $w=\frac{V^{\prime}}{U^{\prime}}$ where $w$ is the wage, $V^{\prime}$ is the marginal utility of leisure, and $U^{\prime}$ is the marginal utility of consumption. Holding the wage constant, if consumption decreases then labor should also increase (leisure decrease). See Hall 1980. Among those not retired, 20 percent reported that they or their spouse went back to work and almost 40 percent indicated that they would defer retirement. These increases in labor supply are associated with about a 2 percentage point decline in consumption (Table 9B, Columns 2 and 3). Deferring retirement by one year corresponds to a 0.4 point reduction in consumption (Column 4). Decreasing or increasing hours are both associated with lower consumption relative to no change in hours (Column 5). This U-shaped pattern may arise from disparate reasons for changing hours: increasing hours in response to lower wealth versus decreasing hours owing to involuntary 
cutbacks in work. Putting these margins of adjustment of labor together in Table 9B, column 6, the effect of job loss and returning to work is somewhat attenuated while the comovement of years of work and consumption remains essentially unchanged.

Summary. The last column of Table 9B includes the cognition, financial distress, and labor supply covariates jointly. Cognition and financial distress remain statistically significant in this specification. The size of the effect of cognition is also largely unaffected by the inclusion of the other covariates. Controlling for wealth, financial distress, labor supply, and demographics, there is a strong effect of having high cognition in limiting the consumption effects of the crisis. Financial distress's effect on consumption is modestly attenuated in the full multivariate specification, though it remains a very significant correlate of adverse effects of the crisis.

\section{Delays in Vehicle Purchases}

Changes in automobile purchases during the crisis are of special interest for several reasons. Because vehicles are durable, their purchase can be very sensitive to economic conditions. For a household that already owns a serviceable vehicle, deferring a purchase can be a relatively attractive margin for adjusting to tight credit, reduced income or wealth, or uncertainty about future economic conditions. There is little loss in utility from holding onto a vehicle a bit longer than planned. The decline in vehicle sales was indeed one of the important factors that magnified the effect of the financial crisis on economic activity.

Tables 10A and 10B examine what factors led to the deferral of purchases of vehicles. They report estimates of a probit model where the dependent variable is one if the household deferred the purchase and zero otherwise. The tables report marginal effects evaluated at the 
mean of the data. Interesting, neither change in financial assets nor the fall in home values is associated with the decision to defer a purchase. Adverse labor market outcomes are a key factor for explaining deferral of vehicle purchases. For example, the marginal effect of job loss is about 0.5 . Similarly, going back to work or deferring retirement is strongly associated with deferral.

The financial distress indicator is also a powerful indicator for deferring the purchase of a vehicle. The marginal effect of having the financial stress indicator (responding in the affirmative to at least two of the seven indicators of financial distress) is about 0.6. Hence, tightness of credit markets and adverse labor market conditions are important factors in understanding the decline in vehicle purchases. The results point to these factors, rather than the loss of wealth associated with the financial crisis, as the determinants of the collapse in vehicle demand.

\section{Summary}

The CogEcon Post-crash survey has a rich set of covariates that help explain why the effects of the financial crisis were so widespread. The paper presents multivariate analyses of the effects of the financial crisis, taking the decline in planned consumption as the indicator of the effects of the crisis.

- Having financial losses is strongly associated with a decline in consumption. For the mean household with financial assets, these losses reduce consumption by about 0.3 percentage points.

- Having little or no financial wealth is, however, associated with even larger drops in consumption. 
- Within the population aged 50 years and older, homeownership is ubiquitous. Almost $90 \%$ of the CogEcon respondents are homeowners. The declines in house values they report is about the same as the average decline in wealth. Across households, the decline in house values accounts for roughly the same amount of the decline in consumption as the decline in financial wealth.

- A substantial minority of households report financial distress. Housing-related financial distress is rare in this population. Being denied credit or making a late payment is more common. Financial distress is much more common among the non-wealth holders. They are five times more likely to report more than one indicator of financial distress than those with positive financial wealth.

- Reductions in leisure - in the form of returning to work and postponing retirement are also common responses to the financial crisis and go hand in hand with the decrease in consumption.

- Controlling for a broad range of financial factors, there remains a role for the level of cognition in explaining the effects of the financial crisis. 


\section{References}

Barsky, Robert B., F. Thomas Juster, Miles S. Kimball, and Matthew D. Shapiro, "Preference Parameters and Behavioral Heterogeneity: An Experimental Approach in the Health and Retirement Study” Quarterly Journal of Economics 112 (May 1997) 537-579.

Goda, Gopi Shah, John B. Shoven and Sita Nataraj Slavov, “Does Stock Market Performance Influence Retirement Expectations?” NBER Working Paper No. 16211 (2010).

Hall, Robert E. "Stochastic Implications of the Life Cycle-Permanent Income Hypothesis: Theory and Evidence.” Journal of Political Economy 86 (December 1978) 971-987.

Hall, Robert E. “Labor Supply and Aggregate Fluctuation” Carnegie-Rochester Conference Series on Public Policy 12 (1980) 7-33.

Hall, Robert E. “Intertemporal Substitution in Consumption” Journal of Political Economy 96 (April 1988) 339-357.

Hurd, Michael D., Monika Reti, and Susann Rohwedder. "The Effect of Large Capital Gains or Losses on Retirement.” Development in the Economics of Aging (David A. Wise, ed.), University of Chicago Press, forthcoming.

Kimball, Miles S. Claudia R. Sahm, and Matthew D. Shapiro. "Imputing Risk Tolerance from Survey Responses” Journal of the American Statistical Association 103 (Sept 2008) 1028-1038.

Mankiw, N. Gregory. “Hall's consumption hypothesis and durable goods.” Journal of Monetary Economics 10 (1982) 417-425.

Palumbo, Michael G., Jeremy Rudd and Karl Whelan. "On the Relationships between Real Consumption, Income, and Wealth”, Journal of Business and Economic Statistics 24 (January 2006) 1-11.

Sevak, Purvi. "Wealth Shocks and Retirement Timing: Evidence from the Nineties.” Michigan Retirement Research Center Working Paper 2002-027.

Shapiro, Matthew D. "Risk tolerance, cognition, and the demand for risk assets.” In progress, University of Michigan (2010). 
Table 1. Financial Wealth and the Financial Crisis

\begin{tabular}{cccccccc}
\hline & \multicolumn{2}{c}{ Financial wealth, July 2008 } & \multicolumn{5}{c}{ Percent change since July 2008 } \\
& Mean & Median & Mean & $25^{\text {th }}$ ptile & Median & $75^{\text {th }}$ ptile & Obs. \\
\hline$\geq \$ 10,000$ wealth & $\$ 516,123$ & $\$ 270,001$ & $-15.2 \%$ & $-29.1 \%$ & $-15.0 \%$ & $-0.6 \%$ & 655 \\
Lost $\geq 10 \%$ & $\$ 628,182$ & $\$ 402,432$ & $-28.7 \%$ & $-35.5 \%$ & $-26.8 \%$ & $-19.1 \%$ & 385 \\
Lost $<10 \%$ & $\$ 356,336$ & $\$ 122,404$ & $4.0 \%$ & $-4.7 \%$ & $0.0 \%$ & $3.3 \%$ & 270 \\
By fluid intelligence & & & & & & & \\
$\quad$ Bottom third & $\$ 370,142$ & $\$ 145,390$ & $-12.1 \%$ & $-24.2 \%$ & $-8.4 \%$ & $0.0 \%$ & 162 \\
Middle third & $\$ 473,951$ & $\$ 263,820$ & $-14.4 \%$ & $-28.0 \%$ & $-14.3 \%$ & $0.0 \%$ & 256 \\
Top third & $\$ 661,461$ & $\$ 386,551$ & $-18.3 \%$ & $-32.5 \%$ & $-20.0 \%$ & $-5.8 \%$ & 237 \\
$<\$ 10,000$ wealth & $\$ 2,745$ & $\$ 1,251$ & $-3.4 \%$ & $0.0 \%$ & $0.0 \%$ & $0.0 \%$ & 140 \\
\hline
\end{tabular}

Source: Wealth (retirement accounts plus cash and stock outside of retirement accounts) is from the CogEcon 2009 Post-crash survey. Fluid intelligence (number series score) is from the CogUSA survey.

Table 2. Wealth by Type

\begin{tabular}{lccccccc}
\hline & \multicolumn{2}{c}{ Wealth, July 2008 } & \multicolumn{5}{c}{ Percent change since July 2008 } \\
& Mean & Median & Mean & $25^{\text {th }}$ ptile & Median & $75^{\text {th }}$ ptile & Obs. \\
\hline Total financial & $\$ 516,123$ & $\$ 270,001$ & $-15.2 \%$ & $-29.1 \%$ & $-15.0 \%$ & $-0.6 \%$ & 655 \\
Retirement & $\$ 293,077$ & $\$ 150,000$ & $-18.9 \%$ & $-33.0 \%$ & $-20.0 \%$ & $0.0 \%$ & 592 \\
Cash & $\$ 110,913$ & $\$ 25,761$ & $1.3 \%$ & $-10.0 \%$ & $0.0 \%$ & $3.0 \%$ & 619 \\
Stock & $\$ 199,801$ & $\$ 31,250$ & $-20.2 \%$ & $-35.0 \%$ & $-20.0 \%$ & $0.0 \%$ & 480 \\
Home & $\$ 326,804$ & $\$ 213,890$ & $-8.8 \%$ & $-15.0 \%$ & $-10.0 \%$ & $0.0 \%$ & 719 \\
Doesn't own home & & & & & & & 83 \\
\hline
\end{tabular}

Source: CogEcon 2009 Post-Crash survey. For financial wealth, excludes respondents with less than $\$ 10,000$ total financial wealth. 
Table 3. 2008 Share of Stock in Financial Wealth

\begin{tabular}{lccccc}
\hline & Mean & $25^{\text {th }}$ ptile & Median & $75^{\text {th }}$ ptile & Obs. \\
\hline All & $36.6 \%$ & $0.0 \%$ & $30.1 \%$ & $64.1 \%$ & 633 \\
$\begin{array}{l}\text { By fluid intelligence } \\
\quad \text { Bottom third }\end{array}$ & & & & \\
$\quad$ Middle third & $28.0 \%$ & $0.0 \%$ & $7.2 \%$ & $54.1 \%$ & 151 \\
$\quad$ Top third & $36.7 \%$ & $1.4 \%$ & $31.0 \%$ & $60.9 \%$ & 252 \\
\hline
\end{tabular}

Includes only those with at least \$10,000 in financial wealth in 2008

Table 4. Relative Risk Tolerance

\begin{tabular}{lccccc}
\hline & Mean & $25^{\text {th }}$ ptile & Median & $75^{\text {th }}$ ptile & Obs. \\
\hline All & 0.313 & 0.159 & 0.245 & 0.344 & 941 \\
By fluid intelligence & & & & & \\
$\quad$ Bottom third & 0.257 & 0.099 & 0.159 & 0.279 & 280 \\
$\quad$ Middle third & 0.316 & 0.159 & 0.245 & 0.344 & 360 \\
$\quad$ Top third & 0.363 & 0.225 & 0.335 & 0.426 & 301 \\
\hline
\end{tabular}

Table 5. Economic and Cognition Status Variables

\begin{tabular}{lcccc}
\hline & $\begin{array}{c}2008 \text { household } \\
\text { income }\end{array}$ & $\begin{array}{c}2008 \text { food } \\
\text { consumption }\end{array}$ & $\begin{array}{c}2008 \text { wealth } \\
\text { (imputed) }\end{array}$ & $\begin{array}{c}\text { Number series } \\
\text { score }\end{array}$ \\
$\begin{array}{l}\text { Responses } \\
\text { Mean }\end{array}$ & 876 & 902 & 795 & 942 \\
$\begin{array}{l}\text { Median } \\
33^{\text {rd }}\end{array}$ & $\$ 116,188$ & $\$ 184$ & $\$ 425,717$ & 521 \\
percentile & $\$ 42,000$ & $\$ 139$ & $\$ 165,138$ & 522 \\
$67^{\text {th }}$ & $\$ 110$ & $\$ 62,007$ & 510 \\
percentile & $\$ 90,000$ & $\$ 175$ & $\$ 367,685$ & 531 \\
\hline
\end{tabular}

Source: CogEcon 2008 and CogUSA. Number series is scored so the population average is 500, so the CogUSA has above-average cognition. 
Table 6. Financial Distress Indicators

\begin{tabular}{|c|c|c|c|c|c|c|c|c|c|c|c|c|}
\hline & \multirow[t]{2}{*}{ All } & \multicolumn{2}{|c|}{ Retired } & \multicolumn{3}{|c|}{ Number series tercile } & \multicolumn{2}{|c|}{ Own home } & \multicolumn{2}{|c|}{ Wealth lost in crisis } & \multirow{2}{*}{$\begin{array}{c}\text { Wealth } \\
<\$ 10,000\end{array}$} & \multirow[t]{2}{*}{ Obs } \\
\hline & & No & Yes & 1 (low) & 2 & 3 (high) & No & Yes & $\geq 10 \%$ & $<10 \%$ & & \\
\hline Pawnshop loan, etc & $1.2 \%$ & $1.5 \%$ & $0.6 \%$ & $2.1 \%$ & $1.0 \%$ & $0.7 \%$ & $1.2 \%$ & $1.2 \%$ & $1.1 \%$ & $0.7 \%$ & $1.9 \%$ & 816 \\
\hline Late payment & $9.9 \%$ & $12.6 \%$ & $5.4 \%$ & $12.9 \%$ & $8.4 \%$ & $9.0 \%$ & $18.5 \%$ & $9.0 \%$ & $6.3 \%$ & $6.0 \%$ & $25.6 \%$ & 817 \\
\hline Denied credit & $6.9 \%$ & $8.7 \%$ & $3.8 \%$ & $11.3 \%$ & $5.5 \%$ & $4.5 \%$ & $18.5 \%$ & $5.6 \%$ & $4.0 \%$ & $4.1 \%$ & $18.7 \%$ & 815 \\
\hline Foreclosure & $0.6 \%$ & $0.6 \%$ & $0.6 \%$ & $1.3 \%$ & $0.3 \%$ & $0.4 \%$ & $3.7 \%$ & $0.3 \%$ & $0.5 \%$ & $0.0 \%$ & $1.9 \%$ & 817 \\
\hline Financial help & $4.8 \%$ & $5.4 \%$ & $3.5 \%$ & $5.8 \%$ & $4.9 \%$ & $3.7 \%$ & $17.3 \%$ & $3.4 \%$ & $2.6 \%$ & $3.4 \%$ & $12.2 \%$ & 817 \\
\hline Cancelled credit & $3.9 \%$ & $4.1 \%$ & $3.2 \%$ & $5.0 \%$ & $3.2 \%$ & $3.7 \%$ & $8.6 \%$ & $3.4 \%$ & $3.2 \%$ & $1.9 \%$ & $9.6 \%$ & 817 \\
\hline Reduced credit & $11.4 \%$ & $14.3 \%$ & $7.1 \%$ & $14.2 \%$ & $8.1 \%$ & $12.7 \%$ & $16.0 \%$ & $10.9 \%$ & $9.0 \%$ & $10.1 \%$ & $19.9 \%$ & 815 \\
\hline Yes to any & $24.0 \%$ & $29.2 \%$ & $15.7 \%$ & $28.6 \%$ & $21.4 \%$ & $22.8 \%$ & $39.5 \%$ & $22.3 \%$ & $19.5 \%$ & $19.0 \%$ & $43.6 \%$ & 818 \\
\hline Yes to 2 or more & $8.4 \%$ & $11.2 \%$ & $4.2 \%$ & $11.2 \%$ & $7.4 \%$ & $7.1 \%$ & $19.8 \%$ & $7.2 \%$ & $4.2 \%$ & $5.2 \%$ & $24.4 \%$ & 818 \\
\hline
\end{tabular}

Note: Table shows percent responding yes to question indicated in row. Source: CogEcon 2009 Post-Crash. 
Table 7. Labor Market Status, Outcomes, and Adjustments.

\begin{tabular}{|c|c|c|c|c|c|c|c|c|c|c|}
\hline & \multirow[t]{2}{*}{ All } & \multicolumn{3}{|c|}{ Number series tercile } & \multicolumn{2}{|c|}{ Own home } & \multicolumn{2}{|c|}{ Wealth lost in crisis } & \multirow{2}{*}{$\begin{array}{r}\text { Wealth } \\
<\$ 10,000\end{array}$} & \multirow[t]{2}{*}{ Obs } \\
\hline & & 1 (low) & 2 & 3 (high) & No & Yes & $\geq 10 \%$ & $<10 \%$ & & \\
\hline Retired & $39.5 \%$ & $57.9 \%$ & $40.1 \%$ & $22.4 \%$ & $55.6 \%$ & $37.4 \%$ & $32.3 \%$ & $44.3 \%$ & $47.3 \%$ & 805 \\
\hline Not retired & $60.5 \%$ & $42.1 \%$ & $59.9 \%$ & $77.6 \%$ & $44.4 \%$ & $62.6 \%$ & $67.7 \%$ & $55.7 \%$ & $52.7 \%$ & 805 \\
\hline Increased hours & $12.4 \%$ & $14.9 \%$ & $12.4 \%$ & $11.3 \%$ & $15.2 \%$ & $12.2 \%$ & $14.3 \%$ & $6.9 \%$ & $13.5 \%$ & 475 \\
\hline Decreased hours & $19.8 \%$ & $14.9 \%$ & $25.8 \%$ & $16.7 \%$ & $21.2 \%$ & $19.7 \%$ & $21.5 \%$ & $19.4 \%$ & $14.9 \%$ & 475 \\
\hline No change in hours & $64.4 \%$ & $66.0 \%$ & $57.3 \%$ & $70.0 \%$ & $57.6 \%$ & $64.9 \%$ & $60.6 \%$ & $70.8 \%$ & $67.6 \%$ & 475 \\
\hline One inc., one decr. & $2.1 \%$ & $1.1 \%$ & $2.8 \%$ & $2.0 \%$ & $3.0 \%$ & $2.0 \%$ & $2.8 \%$ & $1.4 \%$ & $1.4 \%$ & 475 \\
\hline Lost job & $10.1 \%$ & $10.4 \%$ & $8.2 \%$ & $11.8 \%$ & $20.0 \%$ & $9.4 \%$ & $10.7 \%$ & $6.8 \%$ & $15.4 \%$ & 484 \\
\hline Gone back to work & $20.2 \%$ & $21.6 \%$ & $16.9 \%$ & $22.5 \%$ & $37.1 \%$ & $18.9 \%$ & $22.4 \%$ & $14.4 \%$ & $26.0 \%$ & 484 \\
\hline $\begin{array}{l}\text { Change planned } \\
\text { retirement }\end{array}$ & $38.9 \%$ & $32.1 \%$ & $42.6 \%$ & $38.4 \%$ & $25.0 \%$ & $40.0 \%$ & $45.0 \%$ & $30.2 \%$ & $35.3 \%$ & 455 \\
\hline Mean years deferred & 1.32 & 1.15 & 1.67 & 1.09 & 1.75 & 1.29 & 1.47 & 0.95 & 1.60 & 450 \\
\hline
\end{tabular}

Source: CogEcon 2009 Post-crash. Note: Table shows percent responding yes to question indicated in row. Retirement and change in employment variables are defined by household. Couples are considered not retired if at least one member is still working. For couples, increased hours means both partners increased hours or one increased and one stayed the same. Change in work and retirement variables are only tabulated for households with at least one individual not retired in 2009. Year deferred is equal to zero for respondents who did not change planned retirement age. 
Table 8. Change in Consumption as a Result of the Financial Crisis

\begin{tabular}{|c|c|c|c|c|c|c|c|c|c|c|c|c|}
\hline & \multirow[t]{2}{*}{ All } & \multicolumn{2}{|c|}{ Retired } & \multicolumn{3}{|c|}{ Number series tercile } & \multicolumn{2}{|c|}{ Own home } & \multicolumn{2}{|c|}{ Wealth lost in crisis } & \multirow{2}{*}{$\begin{array}{c}\text { Weatlh } \\
<\$ 10,000 \\
\end{array}$} & \multirow[t]{2}{*}{ Obs } \\
\hline & & No & Yes & 1 (low) & 2 & 3 (high) & No & Yes & $\geq 10 \%$ & $<10 \%$ & & \\
\hline & \multicolumn{12}{|c|}{ Mean change } \\
\hline Food at home & $-1.0 \%$ & $-1.4 \%$ & $-0.3 \%$ & $-0.9 \%$ & $-1.0 \%$ & $-1.0 \%$ & $-1.6 \%$ & $-0.9 \%$ & $-1.1 \%$ & $-0.4 \%$ & $-1.8 \%$ & 816 \\
\hline $\begin{array}{l}\text { Food away from } \\
\text { home }\end{array}$ & $-4.5 \%$ & $-5.4 \%$ & $-2.9 \%$ & $-4.3 \%$ & $-4.8 \%$ & $-4.3 \%$ & $-5.7 \%$ & $-4.3 \%$ & $-4.6 \%$ & $-3.1 \%$ & $-6.4 \%$ & 817 \\
\hline Other nondurables & $-4.6 \%$ & $-5.3 \%$ & $-3.3 \%$ & $-4.2 \%$ & $-4.9 \%$ & $-4.5 \%$ & $-5.1 \%$ & $-4.5 \%$ & $-5.0 \%$ & $-3.2 \%$ & $-5.9 \%$ & 813 \\
\hline \multirow[t]{2}{*}{ Composite } & $-3.4 \%$ & $-4.1 \%$ & $-2.2 \%$ & $-3.2 \%$ & $-3.6 \%$ & $-3.3 \%$ & $-4.3 \%$ & $-3.2 \%$ & $-3.6 \%$ & $-2.3 \%$ & $-4.8 \%$ & 805 \\
\hline & \multicolumn{12}{|c|}{ Percent answering yes } \\
\hline $\begin{array}{l}\text { Delayed motor } \\
\text { vehicle purchase }\end{array}$ & $16.0 \%$ & $20.7 \%$ & $8.4 \%$ & $15.1 \%$ & $16.6 \%$ & $16.1 \%$ & $22.8 \%$ & $15.2 \%$ & $16.4 \%$ & $11.5 \%$ & $22.9 \%$ & 813 \\
\hline
\end{tabular}

Source: CogEcon 2009 Post-crash. 
Table 9A. Explaining Change in Consumption, Regressions

\begin{tabular}{|c|c|c|c|c|c|c|}
\hline & 1 & 2 & 3 & 4 & 5 & 6 \\
\hline Change in wealth & $\begin{array}{c}0.019 \\
(0.008)\end{array}$ & $\begin{array}{c}0.021 \\
(0.009)\end{array}$ & $\begin{array}{c}0.020 \\
(0.009)\end{array}$ & $\begin{array}{c}0.031 \\
(0.009)\end{array}$ & $\begin{array}{c}0.031 \\
(0.009)\end{array}$ & $\begin{array}{c}0.033 \\
(0.008)\end{array}$ \\
\hline Wealth $<\$ 10,000$ & $\begin{array}{l}-1.893 \\
(0.552)\end{array}$ & $\begin{array}{l}-1.724 \\
(0.558)\end{array}$ & $\begin{array}{l}-1.748 \\
(0.573)\end{array}$ & $\begin{array}{l}-0.237 \\
(0.820)\end{array}$ & $\begin{array}{l}-0.280 \\
(0.819)\end{array}$ & $\begin{array}{c}0.279 \\
(0.817)\end{array}$ \\
\hline Retired in 2009 & & $\begin{array}{l}0.516 \\
(0.469)\end{array}$ & $\begin{array}{c}0.466 \\
(0.480)\end{array}$ & $\begin{array}{l}0.526 \\
(0.518)\end{array}$ & $\begin{array}{c}0.559 \\
(0.520)\end{array}$ & $\begin{array}{c}0.457 \\
(0.495)\end{array}$ \\
\hline Own home & & & $\begin{array}{c}0.724 \\
(0.655)\end{array}$ & $\begin{array}{l}1.043 \\
(0.669)\end{array}$ & $\begin{array}{l}1.056 \\
(0.673)\end{array}$ & $\begin{array}{c}0.710 \\
(0.626)\end{array}$ \\
\hline $\begin{array}{l}\text { Own* ch. local home } \\
\text { values }\end{array}$ & & & $\begin{array}{c}0.020 \\
(0.011)\end{array}$ & $\begin{array}{l}0.017 \\
(0.012)\end{array}$ & $\begin{array}{c}0.016 \\
(0.012)\end{array}$ & $\begin{array}{c}0.017 \\
(0.012)\end{array}$ \\
\hline Log income 2008 & & & & $\begin{array}{c}0.202 \\
(0.203)\end{array}$ & $\begin{array}{c}0.173 \\
(0.202)\end{array}$ & $\begin{array}{c}0.189 \\
(0.210)\end{array}$ \\
\hline $\begin{array}{l}\text { Log food expenditure } \\
2008\end{array}$ & & & & $\begin{array}{l}-0.185 \\
(0.341)\end{array}$ & $\begin{array}{l}-0.184 \\
(0.341)\end{array}$ & $\begin{array}{l}-0.081 \\
(0.331)\end{array}$ \\
\hline Log wealth 2008 & & & & $\begin{array}{c}0.251 \\
(0.101)\end{array}$ & $\begin{array}{c}0.240 \\
(0.102)\end{array}$ & $\begin{array}{c}0.246 \\
(0.095)\end{array}$ \\
\hline Bottom NS tercile & & & & & $\begin{array}{c}0.231 \\
(0.431)\end{array}$ & \\
\hline Top NS tercile & & & & & $\begin{array}{c}0.866 \\
(0.393)\end{array}$ & \\
\hline $\begin{array}{l}2 \text { or more financial } \\
\text { distress indicators }\end{array}$ & & & & & & $\begin{array}{l}-3.715 \\
(0.692)\end{array}$ \\
\hline Financial resp. & $\begin{array}{l}-0.881 \\
(0.335)\end{array}$ & $\begin{array}{l}-0.781 \\
(0.328)\end{array}$ & $\begin{array}{l}-0.802 \\
(0.332)\end{array}$ & $\begin{array}{l}-0.695 \\
(0.348)\end{array}$ & $\begin{array}{l}-0.724 \\
(0.352)\end{array}$ & $\begin{array}{l}-0.731 \\
(0.342)\end{array}$ \\
\hline Part of a couple & $\begin{array}{c}0.122 \\
(0.401)\end{array}$ & $\begin{array}{c}0.209 \\
(0.406)\end{array}$ & $\begin{array}{l}0.102 \\
(0.428)\end{array}$ & $\begin{array}{l}-0.253 \\
(0.465)\end{array}$ & $\begin{array}{l}-0.239 \\
(0.461)\end{array}$ & $\begin{array}{l}-0.493 \\
(0.456)\end{array}$ \\
\hline Male & $\begin{array}{c}0.840 \\
(0.295)\end{array}$ & $\begin{array}{c}0.803 \\
(0.298)\end{array}$ & $\begin{array}{c}0.774 \\
(0.303)\end{array}$ & $\begin{array}{c}0.650 \\
(0.317)\end{array}$ & $\begin{array}{c}0.580 \\
(0.317)\end{array}$ & $\begin{array}{c}0.620 \\
(0.310)\end{array}$ \\
\hline Education $<12$ & $\begin{array}{c}0.587 \\
(0.676)\end{array}$ & $\begin{array}{c}0.403 \\
(0.678)\end{array}$ & $\begin{array}{c}0.634 \\
(0.699)\end{array}$ & $\begin{array}{l}1.043 \\
(0.704)\end{array}$ & $\begin{array}{l}1.032 \\
(0.702)\end{array}$ & $\begin{array}{c}0.913 \\
(0.704)\end{array}$ \\
\hline Education 13-16 & $\begin{array}{l}-0.710 \\
(0.444)\end{array}$ & $\begin{array}{l}-0.703 \\
(0.441)\end{array}$ & $\begin{array}{c}-0.669 \\
(0.452)\end{array}$ & $\begin{array}{c}-0.765 \\
(0.493)\end{array}$ & $\begin{array}{l}-0.827 \\
(0.501)\end{array}$ & $\begin{array}{l}-0.748 \\
(0.489)\end{array}$ \\
\hline Education $>16$ & $\begin{array}{l}-1.015 \\
(0.525)\end{array}$ & $\begin{array}{l}-0.939 \\
(0.527)\end{array}$ & $\begin{array}{l}-0.903 \\
(0.546)\end{array}$ & $\begin{array}{l}-1.365 \\
(0.607)\end{array}$ & $\begin{array}{l}-1.585 \\
(0.614)\end{array}$ & $\begin{array}{l}-1.339 \\
(0.597)\end{array}$ \\
\hline Black & $\begin{array}{l}-1.804 \\
(0.986)\end{array}$ & $\begin{array}{l}-1.981 \\
(1.059)\end{array}$ & $\begin{array}{c}-2.084 \\
(1.135)\end{array}$ & $\begin{array}{c}-1.758 \\
(1.267)\end{array}$ & $\begin{array}{l}-1.733 \\
(1.247)\end{array}$ & $\begin{array}{l}-1.649 \\
(1.198)\end{array}$ \\
\hline Hispanic & $\begin{array}{c}0.227 \\
(1.769)\end{array}$ & $\begin{array}{c}0.236 \\
(1.720)\end{array}$ & $\begin{array}{c}0.650 \\
(1.953)\end{array}$ & $\begin{array}{c}0.836 \\
(2.168)\end{array}$ & $\begin{array}{c}0.903 \\
(2.153)\end{array}$ & $\begin{array}{c}1.481 \\
(1.864)\end{array}$ \\
\hline Age/10 & $\begin{array}{c}1.131 \\
(0.160)\end{array}$ & $\begin{array}{c}0.988 \\
(0.211)\end{array}$ & $\begin{array}{c}0.997 \\
(0.218)\end{array}$ & $\begin{array}{c}0.981 \\
(0.245)\end{array}$ & $\begin{array}{c}1.048 \\
(0.244)\end{array}$ & $\begin{array}{c}0.820 \\
(0.239)\end{array}$ \\
\hline Constant & $\begin{array}{l}-9.208 \\
(1.364)\end{array}$ & $\begin{array}{c}-8.619 \\
(1.556)\end{array}$ & $\begin{array}{c}-9.098 \\
(1.694)\end{array}$ & $\begin{array}{c}-13.224 \\
(3.179)\end{array}$ & $\begin{array}{r}-13.462 \\
(3.192)\end{array}$ & $\begin{array}{l}-11.737 \\
(3.114)\end{array}$ \\
\hline $\mathrm{N}$ & 788 & 767 & 748 & 669 & 669 & 669 \\
\hline R-squared & 0.132 & 0.134 & 0.138 & 0.155 & 0.161 & 0.198 \\
\hline
\end{tabular}

Note Change in wealth is set to zero for individuals with less than $\$ 10,000$ in wealth in 2009. Standard errors clustered by household. 
Table 9B. Explaining Change in Consumption, Regressions

\begin{tabular}{|c|c|c|c|c|c|c|c|}
\hline & 1 & 2 & 3 & 4 & 5 & 6 & 7 \\
\hline \multirow[t]{2}{*}{ Change in wealth } & 0.031 & 0.028 & 0.030 & 0.030 & 0.030 & 0.028 & 0.030 \\
\hline & $(0.009)$ & $(0.008)$ & $(0.009)$ & $(0.009)$ & $(0.009)$ & $(0.009)$ & $(0.009)$ \\
\hline \multirow[t]{2}{*}{ Wealth $<\$ 10,000$} & -0.181 & -0.229 & 0.006 & -0.054 & -0.210 & -0.054 & 0.372 \\
\hline & $(0.816)$ & $(0.811)$ & $(0.797)$ & $(0.791)$ & $(0.799)$ & $(0.773)$ & $(0.777)$ \\
\hline \multirow[t]{2}{*}{ Retired in 2009} & 0.288 & 0.211 & -0.248 & 0.103 & 0.158 & -0.492 & -0.412 \\
\hline & $(0.523)$ & $(0.529)$ & $(0.540)$ & $(0.536)$ & $(0.549)$ & $(0.572)$ & $(0.554)$ \\
\hline \multirow[t]{2}{*}{ Own home } & 0.761 & 0.950 & 1.368 & 1.160 & 1.216 & 0.884 & 0.689 \\
\hline & $(0.660)$ & $(0.635)$ & $(0.651)$ & $(0.645)$ & $(0.645)$ & $(0.620)$ & $(0.609)$ \\
\hline Own* ch. local & 0.016 & 0.016 & 0.018 & 0.018 & 0.014 & 0.012 & 0.011 \\
\hline home values & $(0.012)$ & $(0.012)$ & $(0.013)$ & $(0.013)$ & $(0.012)$ & $(0.013)$ & $(0.012)$ \\
\hline \multirow{2}{*}{ Log income 2008} & 0.170 & 0.134 & 0.090 & 0.075 & 0.145 & 0.006 & -0.020 \\
\hline & $(0.207)$ & $(0.193)$ & $(0.187)$ & $(0.195)$ & $(0.200)$ & $(0.189)$ & $(0.193)$ \\
\hline Log food & -0.068 & -0.031 & -0.109 & -0.075 & -0.112 & 0.080 & 0.148 \\
\hline expenditure 2008 & $(0.328)$ & $(0.331)$ & $(0.328)$ & $(0.334)$ & $(0.350)$ & $(0.325)$ & $(0.317)$ \\
\hline \multirow{2}{*}{ Log wealth 2008} & 0.254 & 0.256 & 0.332 & 0.304 & 0.288 & 0.309 & 0.290 \\
\hline & $(0.101)$ & (0.099) & $(0.100)$ & $(0.101)$ & $(0.101)$ & (0.099) & $(0.096)$ \\
\hline \multirow[t]{2}{*}{ Bottom NS tercile } & & & & & & & 0.160 \\
\hline & & & & & & & $(0.435)$ \\
\hline \multirow{2}{*}{ Top NS tercile } & & & & & & & 0.930 \\
\hline & & & & & & & $(0.371)$ \\
\hline \multirow{2}{*}{$\begin{array}{l}2 \text { or more financial } \\
\text { distress indicators }\end{array}$} & & & & & & & -2.989 \\
\hline & & & & & & & $(0.711)$ \\
\hline \multirow{2}{*}{$\begin{array}{l}\text { Self or spouse lost } \\
\text { job }\end{array}$} & -2.510 & & & & & -1.196 & -1.067 \\
\hline & $(0.829)$ & & & & & $(0.991)$ & $(0.973)$ \\
\hline \multirow{2}{*}{$\begin{array}{l}\text { Self or spouse } \\
\text { returned to work }\end{array}$} & & -2.089 & & & & -0.726 & -0.702 \\
\hline & & $(0.551)$ & & & & $(0.651)$ & $(0.658)$ \\
\hline \multirow{2}{*}{$\begin{array}{l}\text { Self or spouse } \\
\text { retired later }\end{array}$} & & & -2.201 & & & & \\
\hline & & & $(0.445)$ & -0.377 & & -0.401 & -0.354 \\
\hline $\begin{array}{l}\text { Years deferred } \\
\text { retirement }\end{array}$ & & & & $(0.114)$ & & $(0.123)$ & $(0.128)$ \\
\hline \multirow[t]{2}{*}{ Decreased hours } & & & & & -1.475 & -1.127 & -1.024 \\
\hline & & & & & $(0.569)$ & $(0.606)$ & $(0.594)$ \\
\hline \multirow{2}{*}{ Increased hours } & & & & & -2.089 & -1.529 & -1.461 \\
\hline & & & & & $(0.768)$ & $(0.755)$ & $(0.735)$ \\
\hline \multirow[t]{2}{*}{ Financial resp. } & -0.588 & -0.570 & -0.766 & -0.827 & -0.574 & -0.543 & -0.611 \\
\hline & $(0.345)$ & $(0.355)$ & $(0.348)$ & $(0.357)$ & $(0.348)$ & $(0.350)$ & $(0.353)$ \\
\hline \multirow[t]{2}{*}{ Part of a couple } & -0.147 & -0.253 & -0.398 & -0.389 & -0.361 & -0.326 & -0.511 \\
\hline & $(0.470)$ & $(0.460)$ & $(0.465)$ & $(0.463)$ & $(0.464)$ & $(0.470)$ & $(0.459)$ \\
\hline Male & 0.549 & 0.550 & 0.549 & 0.598 & 0.634 & 0.494 & 0.436 \\
\hline & $(0.317)$ & $(0.316)$ & $(0.320)$ & $(0.320)$ & $(0.314)$ & $(0.317)$ & $(0.312)$ \\
\hline Education $<12$ & 0.987 & 1.108 & 1.297 & 1.237 & 1.250 & 1.378 & 1.199 \\
\hline & $(0.708)$ & $(0.731)$ & $(0.690)$ & $(0.667)$ & (0.694) & $(0.653)$ & $(0.661)$ \\
\hline Education 13-16 & -0.761 & -0.696 & -0.790 & -0.770 & -0.896 & -0.784 & -0.862 \\
\hline & $(0.488)$ & $(0.497)$ & $(0.490)$ & $(0.498)$ & $(0.497)$ & $(0.502)$ & $(0.506)$ \\
\hline Education $>16$ & -1.283 & -1.195 & -1.278 & -1.288 & -1.540 & -1.271 & -1.513 \\
\hline & $(0.595)$ & $(0.601)$ & $(0.597)$ & $(0.601)$ & $(0.607)$ & $(0.601)$ & $(0.600)$ \\
\hline Black & -1.717 & -1.582 & -1.646 & -1.642 & -1.954 & -1.962 & -1.698 \\
\hline & $(1.310)$ & (1.312) & (1.386) & $(1.401)$ & (1.271) & (1.423) & (1.311) \\
\hline Hispanic & 0.670 & 1.156 & -2.053 & -1.783 & 1.554 & -1.560 & 0.117 \\
\hline & (2.139) & (1.999) & $(0.722)$ & $(0.662)$ & (2.703) & $(0.837)$ & $(0.714)$ \\
\hline Age/10 & 0.981 & 0.942 & 0.955 & 0.959 & 0.864 & 0.901 & 0.854 \\
\hline & $(0.247)$ & $(0.249)$ & $(0.244)$ & $(0.246)$ & $(0.253)$ & $(0.252)$ & $(0.250)$ \\
\hline Constant & -13.126 & -12.781 & -12.452 & -12.319 & -12.267 & -11.399 & -10.710 \\
\hline & $(3.175)$ & $(3.170)$ & (3.102) & $(3.152)$ & (3.192) & (3.104) & (3.029) \\
\hline $\mathrm{N}$ & 666 & 666 & 641 & 639 & 659 & 631 & 631 \\
\hline R-squared & 0.17 & 0.177 & 0.208 & 0.201 & 0.181 & 0.233 & 0.267 \\
\hline
\end{tabular}

Note: See Table 9A. 
Table 10A. Explaining Delay in Vehicle Purchase, Probit Regressions

\begin{tabular}{|c|c|c|c|c|c|c|}
\hline & 1 & 2 & 3 & 4 & 5 & 6 \\
\hline Change in wealth & $\begin{array}{l}-0.002 \\
(0.003)\end{array}$ & $\begin{array}{l}-0.002 \\
(0.003)\end{array}$ & $\begin{array}{l}-0.003 \\
(0.003)\end{array}$ & $\begin{array}{l}-0.004 \\
(0.004)\end{array}$ & $\begin{array}{l}-0.004 \\
(0.004)\end{array}$ & $\begin{array}{l}-0.004 \\
(0.004)\end{array}$ \\
\hline Wealth $<\$ 10,000$ & $\begin{array}{c}0.426 \\
(0.151)\end{array}$ & $\begin{array}{l}0.360 \\
(0.154)\end{array}$ & $\begin{array}{c}0.297 \\
(0.161)\end{array}$ & $\begin{array}{l}0.186 \\
(0.250)\end{array}$ & $\begin{array}{c}0.187 \\
(0.250)\end{array}$ & $\begin{array}{c}0.011 \\
(0.265)\end{array}$ \\
\hline Retired in 2009 & & $\begin{array}{l}-0.210 \\
(0.158)\end{array}$ & $\begin{array}{l}-0.197 \\
(0.161)\end{array}$ & $\begin{array}{l}-0.250 \\
(0.173)\end{array}$ & $\begin{array}{l}-0.250 \\
(0.173)\end{array}$ & $\begin{array}{l}-0.223 \\
(0.177)\end{array}$ \\
\hline Own home & & & $\begin{array}{l}-0.448 \\
(0.202)\end{array}$ & $\begin{array}{l}-0.460 \\
(0.221)\end{array}$ & $\begin{array}{l}-0.462 \\
(0.222)\end{array}$ & $\begin{array}{l}-0.369 \\
(0.229)\end{array}$ \\
\hline $\begin{array}{l}\text { Own* ch. local home } \\
\text { values }\end{array}$ & & & $\begin{array}{l}-0.001 \\
(0.005)\end{array}$ & $\begin{array}{l}-0.001 \\
(0.006)\end{array}$ & $\begin{array}{l}-0.001 \\
(0.006)\end{array}$ & $\begin{array}{l}-0.001 \\
(0.006)\end{array}$ \\
\hline Log income 2008 & & & & $\begin{array}{l}-0.166 \\
(0.062)\end{array}$ & $\begin{array}{l}-0.166 \\
(0.062)\end{array}$ & $\begin{array}{l}-0.163 \\
(0.060)\end{array}$ \\
\hline Log food expenditure & & & & $\begin{array}{l}0.059 \\
0.109)\end{array}$ & $\begin{array}{c}0.061 \\
(0.110)\end{array}$ & 0.026 \\
\hline Log wealth 2008 & & & & $\begin{array}{l}-0.011 \\
(0.030)\end{array}$ & $\begin{array}{l}-0.011 \\
(0.030)\end{array}$ & $\begin{array}{l}-0.015 \\
(0.032)\end{array}$ \\
\hline Bottom NS tercile & & & & & $\begin{array}{l}-0.036 \\
(0.171)\end{array}$ & \\
\hline Top NS tercile & & & & & $\begin{array}{l}-0.036 \\
(0.145)\end{array}$ & \\
\hline $\begin{array}{l}2 \text { or more financial } \\
\text { distress indicators }\end{array}$ & & & & & & $\begin{array}{c}0.751 \\
(0.195)\end{array}$ \\
\hline Financial resp. & $\begin{array}{c}0.319 \\
(0.139)\end{array}$ & $\begin{array}{c}0.325 \\
(0.140)\end{array}$ & $\begin{array}{c}0.315 \\
(0.140)\end{array}$ & $\begin{array}{c}0.306 \\
(0.143)\end{array}$ & $\begin{array}{c}0.305 \\
(0.143)\end{array}$ & $\begin{array}{c}0.323 \\
(0.145)\end{array}$ \\
\hline Part of a couple & $\begin{array}{c}0.277 \\
(0.145)\end{array}$ & $\begin{array}{l}0.227 \\
(0.147)\end{array}$ & $\begin{array}{c}0.284 \\
(0.154)\end{array}$ & $\begin{array}{c}0.353 \\
(0.163)\end{array}$ & $\begin{array}{c}0.350 \\
(0.162)\end{array}$ & $\begin{array}{c}0.435 \\
(0.169)\end{array}$ \\
\hline Male & $\begin{array}{l}-0.083 \\
(0.116)\end{array}$ & $\begin{array}{l}-0.089 \\
(0.116)\end{array}$ & $\begin{array}{l}-0.097 \\
(0.117)\end{array}$ & $\begin{array}{l}-0.041 \\
(0.122)\end{array}$ & $\begin{array}{l}-0.039 \\
(0.122)\end{array}$ & $\begin{array}{l}-0.035 \\
(0.126)\end{array}$ \\
\hline Education $<12$ & $\begin{array}{l}-0.223 \\
(0.317)\end{array}$ & $\begin{array}{l}-0.250 \\
(0.353)\end{array}$ & $\begin{array}{l}-0.210 \\
(0.358)\end{array}$ & $\begin{array}{l}-0.193 \\
(0.380)\end{array}$ & $\begin{array}{l}-0.193 \\
(0.379)\end{array}$ & $\begin{array}{l}-0.153 \\
(0.386)\end{array}$ \\
\hline Education 13-16 & $\begin{array}{c}0.016 \\
(0.150)\end{array}$ & $\begin{array}{l}-0.003 \\
(0.153)\end{array}$ & $\begin{array}{l}-0.024 \\
(0.154)\end{array}$ & $\begin{array}{l}-0.002 \\
(0.164)\end{array}$ & $\begin{array}{l}-0.004 \\
(0.171)\end{array}$ & $\begin{array}{c}0.011 \\
(0.166)\end{array}$ \\
\hline Education $>16$ & $\begin{array}{c}0.026 \\
(0.170)\end{array}$ & $\begin{array}{l}-0.008 \\
(0.175)\end{array}$ & $\begin{array}{c}-0.041 \\
(0.177)\end{array}$ & $\begin{array}{c}0.036 \\
(0.192)\end{array}$ & $\begin{array}{c}0.040 \\
(0.201)\end{array}$ & $\begin{array}{c}0.051 \\
(0.194)\end{array}$ \\
\hline Black & $\begin{array}{c}0.144 \\
(0.270)\end{array}$ & $\begin{array}{c}0.203 \\
(0.288)\end{array}$ & $\begin{array}{c}0.003 \\
(0.307)\end{array}$ & $\begin{array}{l}-0.084 \\
(0.351)\end{array}$ & $\begin{array}{c}-0.078 \\
(0.350)\end{array}$ & $\begin{array}{l}-0.018 \\
(0.363)\end{array}$ \\
\hline Hispanic & $\begin{array}{c}0.187 \\
(0.704)\end{array}$ & $\begin{array}{c}0.172 \\
(0.695)\end{array}$ & $\begin{array}{c}0.214 \\
(0.711)\end{array}$ & $\begin{array}{c}0.213 \\
(0.729)\end{array}$ & $\begin{array}{c}0.228 \\
(0.728)\end{array}$ & $\begin{array}{c}0.012 \\
(0.613)\end{array}$ \\
\hline Age/10 & $\begin{array}{l}-0.346 \\
(0.067)\end{array}$ & $\begin{array}{l}-0.287 \\
(0.082)\end{array}$ & $\begin{array}{c}-0.296 \\
(0.084)\end{array}$ & $\begin{array}{c}-0.328 \\
(0.089)\end{array}$ & $\begin{array}{c}-0.329 \\
(0.089)\end{array}$ & $\begin{array}{l}-0.290 \\
(0.090)\end{array}$ \\
\hline Constant & $\begin{array}{c}0.625 \\
(0.477)\end{array}$ & $\begin{array}{c}0.389 \\
(0.530)\end{array}$ & $\begin{array}{c}0.819 \\
(0.580)\end{array}$ & $\begin{array}{c}2.632 \\
(1.039)\end{array}$ & $\begin{array}{c}2.661 \\
(1.041)\end{array}$ & $\begin{array}{c}2.342 \\
(1.032)\end{array}$ \\
\hline $\mathrm{N}$ & 796 & 774 & 754 & 674 & 674 & 670 \\
\hline Pseudo R-squared & 0.078 & 0.078 & 0.08 & 0.098 & 0.099 & 0.12 \\
\hline
\end{tabular}

Note: Dependent variable is one if delayed a vehicle purchase and zero otherwise. Change in wealth is set to zero for individuals with less than $\$ 10,000$ in wealth in 2009. Standard errors clustered by household. Reported coefficients are marginal effects at the mean. 
Table 10B. Explaining Delay in Vehicle Purchase, Probit Regressions

\begin{tabular}{|c|c|c|c|c|c|c|c|}
\hline & 1 & 2 & 3 & 4 & 5 & 6 & 7 \\
\hline Change in wealth & $\begin{array}{l}-0.002 \\
(0.004)\end{array}$ & $\begin{array}{l}-0.003 \\
(0.004)\end{array}$ & $\begin{array}{l}-0.003 \\
(0.003)\end{array}$ & $\begin{array}{l}-0.003 \\
(0.003)\end{array}$ & $\begin{array}{l}-0.003 \\
(0.004)\end{array}$ & $\begin{array}{l}-0.000 \\
(0.004)\end{array}$ & $\begin{array}{l}-0.000 \\
(0.004)\end{array}$ \\
\hline Wealth $<\$ 10,000$ & $\begin{array}{c}0.174 \\
(0.254)\end{array}$ & $\begin{array}{c}0.197 \\
(0.255)\end{array}$ & $\begin{array}{c}0.171 \\
(0.251)\end{array}$ & $\begin{array}{c}0.175 \\
(0.252)\end{array}$ & $\begin{array}{c}0.177 \\
(0.249)\end{array}$ & $\begin{array}{c}0.177 \\
(0.260)\end{array}$ & $\begin{array}{c}0.011 \\
(0.271)\end{array}$ \\
\hline Retired in 2009 & $\begin{array}{l}-0.156 \\
(0.176)\end{array}$ & $\begin{array}{l}-0.147 \\
(0.181)\end{array}$ & $\begin{array}{l}-0.102 \\
(0.188)\end{array}$ & $\begin{array}{l}-0.174 \\
(0.181)\end{array}$ & $\begin{array}{l}-0.203 \\
(0.185)\end{array}$ & $\begin{array}{c}0.007 \\
(0.193)\end{array}$ & $\begin{array}{c}0.023 \\
(0.194)\end{array}$ \\
\hline Own home & $\begin{array}{l}-0.396 \\
(0.229)\end{array}$ & $\begin{array}{l}-0.428 \\
(0.226)\end{array}$ & $\begin{array}{l}-0.576 \\
(0.225)\end{array}$ & $\begin{array}{l}-0.527 \\
(0.227)\end{array}$ & $\begin{array}{l}-0.489 \\
(0.227)\end{array}$ & $\begin{array}{l}-0.459 \\
(0.241)\end{array}$ & $\begin{array}{l}-0.403 \\
(0.247)\end{array}$ \\
\hline $\begin{array}{l}\text { Own* ch. local } \\
\text { home values }\end{array}$ & $\begin{array}{l}-0.002 \\
(0.006)\end{array}$ & $\begin{array}{l}-0.002 \\
(0.006)\end{array}$ & $\begin{array}{l}-0.003 \\
(0.006)\end{array}$ & $\begin{array}{l}-0.003 \\
(0.006)\end{array}$ & $\begin{array}{l}-0.001 \\
(0.006)\end{array}$ & $\begin{array}{l}-0.002 \\
(0.006)\end{array}$ & $\begin{array}{l}-0.002 \\
(0.006)\end{array}$ \\
\hline Log income 2008 & $\begin{array}{l}-0.154 \\
(0.059)\end{array}$ & $\begin{array}{l}-0.155 \\
(0.060)\end{array}$ & $\begin{array}{l}-0.152 \\
(0.065)\end{array}$ & $\begin{array}{l}-0.147 \\
(0.064)\end{array}$ & $\begin{array}{l}-0.158 \\
(0.061)\end{array}$ & $\begin{array}{l}-0.130 \\
(0.060)\end{array}$ & $\begin{array}{l}-0.129 \\
(0.059)\end{array}$ \\
\hline $\begin{array}{l}\text { Log food } \\
\text { expenditure } 2008\end{array}$ & $\begin{array}{c}0.025 \\
(0.111)\end{array}$ & $\begin{array}{c}0.015 \\
(0.111)\end{array}$ & $\begin{array}{c}0.054 \\
(0.111)\end{array}$ & $\begin{array}{c}0.050 \\
(0.111)\end{array}$ & $\begin{array}{c}0.042 \\
(0.107)\end{array}$ & $\begin{array}{l}-0.014 \\
(0.113)\end{array}$ & $\begin{array}{l}-0.035 \\
(0.111)\end{array}$ \\
\hline Log wealth 2008 & $\begin{array}{l}-0.012 \\
(0.031)\end{array}$ & $\begin{array}{l}-0.011 \\
(0.031)\end{array}$ & $\begin{array}{l}-0.019 \\
(0.031)\end{array}$ & $\begin{array}{l}-0.014 \\
(0.032)\end{array}$ & $\begin{array}{l}-0.018 \\
(0.031)\end{array}$ & $\begin{array}{l}-0.014 \\
(0.033)\end{array}$ & $\begin{array}{l}-0.019 \\
(0.034)\end{array}$ \\
\hline Bottom NS tercile & & & & & & & $\begin{array}{l}-0.011 \\
(0.186)\end{array}$ \\
\hline Top NS tercile & & & & & & & $\begin{array}{l}-0.029 \\
(0.155)\end{array}$ \\
\hline $\begin{array}{l}2 \text { or more financial } \\
\text { distress indicators }\end{array}$ & & & & & & & $\begin{array}{c}0.654 \\
(0.201)\end{array}$ \\
\hline $\begin{array}{l}\text { Self or spouse lost } \\
\text { job }\end{array}$ & $\begin{array}{c}0.513 \\
(0.216)\end{array}$ & & & & & $\begin{array}{c}0.285 \\
(0.273)\end{array}$ & $\begin{array}{c}0.239 \\
(0.257)\end{array}$ \\
\hline $\begin{array}{l}\text { Self or spouse } \\
\text { returned to work }\end{array}$ & & $\begin{array}{c}0.544 \\
(0.170)\end{array}$ & & & & $\begin{array}{c}0.336 \\
(0.205)\end{array}$ & $\begin{array}{c}0.321 \\
(0.204)\end{array}$ \\
\hline $\begin{array}{l}\text { Self or spouse } \\
\text { retired later }\end{array}$ & & & $\begin{array}{c}0.458 \\
(0.151)\end{array}$ & & & & \\
\hline $\begin{array}{l}\text { Years deferred } \\
\text { retirement }\end{array}$ & & & & $\begin{array}{c}0.085 \\
(0.031)\end{array}$ & & $\begin{array}{c}0.092 \\
(0.035)\end{array}$ & $\begin{array}{c}0.089 \\
(0.035)\end{array}$ \\
\hline Decreased hours & & & & & $\begin{array}{c}0.212 \\
(0.184)\end{array}$ & $\begin{array}{c}0.109 \\
(0.211)\end{array}$ & $\begin{array}{c}0.115 \\
(0.213)\end{array}$ \\
\hline Increased hours & & & & & $\begin{array}{c}0.519 \\
(0.218)\end{array}$ & $\begin{array}{c}0.413 \\
(0.235)\end{array}$ & $\begin{array}{c}0.420 \\
(0.235)\end{array}$ \\
\hline Financial resp. & $\begin{array}{c}0.284 \\
(0.144)\end{array}$ & $\begin{array}{c}0.260 \\
(0.143)\end{array}$ & $\begin{array}{c}0.289 \\
(0.149)\end{array}$ & $\begin{array}{c}0.295 \\
(0.147)\end{array}$ & $\begin{array}{c}0.262 \\
(0.143)\end{array}$ & $\begin{array}{c}0.208 \\
(0.147)\end{array}$ & $\begin{array}{c}0.230 \\
(0.150)\end{array}$ \\
\hline Part of a couple & $\begin{array}{c}0.366 \\
(0.164)\end{array}$ & $\begin{array}{c}0.362 \\
(0.167)\end{array}$ & $\begin{array}{c}0.381 \\
(0.165)\end{array}$ & $\begin{array}{c}0.381 \\
(0.168)\end{array}$ & $\begin{array}{c}0.382 \\
(0.165)\end{array}$ & $\begin{array}{c}0.429 \\
(0.176)\end{array}$ & $\begin{array}{c}0.499 \\
(0.179)\end{array}$ \\
\hline Male & $\begin{array}{l}-0.031 \\
(0.124)\end{array}$ & $\begin{array}{l}-0.019 \\
(0.123)\end{array}$ & $\begin{array}{l}-0.011 \\
(0.126)\end{array}$ & $\begin{array}{l}-0.035 \\
(0.125)\end{array}$ & $\begin{array}{l}-0.028 \\
(0.122)\end{array}$ & $\begin{array}{l}-0.015 \\
(0.128)\end{array}$ & $\begin{array}{l}-0.012 \\
(0.131)\end{array}$ \\
\hline Education $<12$ & $\begin{array}{l}-0.171 \\
(0.378)\end{array}$ & $\begin{array}{l}-0.199 \\
(0.382)\end{array}$ & $\begin{array}{l}-0.171 \\
(0.388)\end{array}$ & $\begin{array}{l}-0.189 \\
(0.390)\end{array}$ & $\begin{array}{l}-0.287 \\
(0.376)\end{array}$ & $\begin{array}{l}-0.251 \\
(0.387)\end{array}$ & $\begin{array}{l}-0.200 \\
(0.389)\end{array}$ \\
\hline Education 13-16 & $\begin{array}{l}-0.002 \\
(0.165)\end{array}$ & $\begin{array}{l}-0.014 \\
(0.166)\end{array}$ & $\begin{array}{c}0.029 \\
(0.172)\end{array}$ & $\begin{array}{c}0.003 \\
(0.174)\end{array}$ & $\begin{array}{c}0.014 \\
(0.165)\end{array}$ & $\begin{array}{l}-0.008 \\
(0.178)\end{array}$ & $\begin{array}{c}0.009 \\
(0.185)\end{array}$ \\
\hline Education $>16$ & $\begin{array}{c}0.029 \\
(0.194)\end{array}$ & $\begin{array}{l}-0.005 \\
(0.197)\end{array}$ & $\begin{array}{c}0.044 \\
(0.198)\end{array}$ & $\begin{array}{c}0.031 \\
(0.198)\end{array}$ & $\begin{array}{c}0.070 \\
(0.193)\end{array}$ & $\begin{array}{c}0.025 \\
(0.202)\end{array}$ & $\begin{array}{c}0.044 \\
(0.212)\end{array}$ \\
\hline Black & $\begin{array}{l}-0.078 \\
(0.344)\end{array}$ & $\begin{array}{l}-0.134 \\
(0.356)\end{array}$ & $\begin{array}{l}-0.207 \\
(0.369)\end{array}$ & $\begin{array}{l}-0.196 \\
(0.369)\end{array}$ & $\begin{array}{l}-0.019 \\
(0.353)\end{array}$ & $\begin{array}{l}-0.078 \\
(0.376)\end{array}$ & $\begin{array}{l}-0.067 \\
(0.372)\end{array}$ \\
\hline Hispanic & $\begin{array}{c}0.234 \\
(0.735)\end{array}$ & $\begin{array}{c}0.078 \\
(0.665)\end{array}$ & $\begin{array}{c}0.846 \\
(0.649)\end{array}$ & $\begin{array}{c}0.781 \\
(0.646)\end{array}$ & $\begin{array}{c}0.457 \\
(0.833)\end{array}$ & $\begin{array}{l}1.200 \\
(0.691)\end{array}$ & $\begin{array}{c}0.893 \\
(0.619)\end{array}$ \\
\hline Age/10 & $\begin{array}{l}-0.342 \\
(0.091)\end{array}$ & $\begin{array}{l}-0.314 \\
(0.090)\end{array}$ & $\begin{array}{l}-0.300 \\
(0.092)\end{array}$ & $\begin{array}{l}-0.297 \\
(0.091)\end{array}$ & $\begin{array}{l}-0.282 \\
(0.089)\end{array}$ & $\begin{array}{l}-0.280 \\
(0.093)\end{array}$ & $\begin{array}{l}-0.255 \\
(0.093)\end{array}$ \\
\hline Constant & $\begin{array}{c}2.649 \\
(1.038)\end{array}$ & $\begin{array}{c}2.547 \\
(1.050)\end{array}$ & $\begin{array}{c}2.294 \\
(1.091)\end{array}$ & $\begin{array}{c}2.258 \\
(1.079)\end{array}$ & $\begin{array}{c}2.372 \\
(1.048)\end{array}$ & $\begin{array}{c}2.101 \\
(1.090)\end{array}$ & $\begin{array}{c}1.914 \\
(1.088)\end{array}$ \\
\hline $\mathrm{N}$ & 671 & 671 & 646 & 643 & 664 & 635 & 632 \\
\hline Pseudo R-squared & 0.107 & 0.116 & 0.119 & 0.116 & 0.111 & 0.141 & 0.157 \\
\hline
\end{tabular}

Note: See Table 10A. 